\title{
Gubernatorial Elections and Security Challenges in Ekiti - State, Nigeria
}

\author{
Ilori, Oladapo Mayowa \\ Department of Sociology, Faculty of the Social Sciences,Ekiti State University, Ado Ekiti
}

\begin{abstract}
Since the return of this present democratic government in $29^{\text {th }}$ May, 1999, Ekiti State has witnessed five different gubernatorial elections; the first in 1998, the second in 2003, the third in 2007, the fourth in 2014 and the fifth in 2018. These elections have been characterised by peace and violence. The first election held in 1998 was peaceful basically because it was conducted by the Independence National Electoral Commission (INEC) and supervised by the then outgoing military Head-of-State Gen Abdulsalam Abubakar (Rtd). However, subsequent gubernatorial elections conducted by democratically elected government have been marred by series of electoral violence and security challenges ranging from ballot boxes snatching, stuffing, intimidation of opposition candidates, killings, votes buying to votes rigging. It is not an understatement to say that gubernatorial elections conducted by elected government are far from reflecting the people's mandate. Security challenges during gubernatorial elections in the state has given rise to voters apathy and this came to a climax in year 2010 when the Court of Appeal in Ilorin had to decide the authentic winner of the gubernatorial election held in 2007 because of widespread violence and manipulation during the election. This paper interrogates security challenges in Ekiti state during gubernatorial elections. Data for this paper was obtained from secondary sources from records and reports of the past gubernatorial elections in the state.
\end{abstract}

Keywords: Gubernatorial, Elections, Violence, Voters, Manipulation, Ekiti state.

DOI: $10.7176 /$ RHSS/9-6-02

Publication date:March $31^{\text {st }} 2019$

\section{INTRODUCTION}

Ekiti state in south-western Nigeria, was declared a state on $1^{\text {st }}$ October, 1996 alongside five other states in the federation by the military junta under late ((Gen.) Sanni Abacha. As one of the newest states of the Nigerian federation, it was carved out of the territory of old Ondo state, and covers the former 12 local government areas that made up the Ekiti region of the old Ondo state. On creation, it had 16 local government areas, having had an additional four carved out of the old ones. Ekiti state is one of the 36 states that constitute Nigeria. Ekiti state is mainly an upland zone, rising over 250 meters above the sea level. It lies on an area underlain by metamorphic rock. It is generally an undulating part of the country with a characteristic landscape that consists of old plains broken by step sided out crops that may occur singularly or in groups or ridges. The state enjoys tropical climate with two distinct seasons, namely: dry and rainy seasons. Ekiti state is a culturally homogeneous state with the people speaking the same language known as ekiti. The homogeneous nature of the state confers on the state some uniqueness among the states in Nigeria.

Ekiti state, since its creation in 1996 has witnessed a number of elections ranging from the local government election, the state house of assembly elections, the gubernatorial elections to both the national assembly elections and the presidential elections. These elections were either peaceful or marred with violence. The type of violence during these elections included ballot boxes snatching, ballot boxes stuffing, beating of INEC officials and votes buying (as witnessed in the just concluded gubernatorial election in the state). Infact, the issue of votes trading came to a climax during the July, $14^{\text {th }} 2018$ gubernatorial elections in the state. It reached an alarming state that the politicians spread their tentacles of inducements to election officials, security agencies, election observers and the media. But this was subsequently condemned with and outside the state. Vote trading has heighten political corruption as those who invested huge amount to procure election victory are not altruistic philanthropists but shrewd businessmen who hope to reap bountiful rewards through corrupt means.

However, the security agencies which ordinarily are empowered to be neutral in the electioneering and during the process of voting have not live to expectation. We even have some situations in which the security agencies will pose the attitude of "I don't care" to the violence at the polling boots. Probably, one of the most defective practises is that the security is not always armed at the poling boots and this is in accordance with international practices.

The politicians are not helping matters either; the political class in respect of the political affiliation are also in the habit of fomenting violence before during or after elections to establish their political dominance. The political class has always demonstrated their bestial nature by turning a routine civic exercise to a power struggle between and/or among the contending political camps. Cyril Omoregbe, the Resident Electoral Commissioner (REC) in Bayelsa state "electoral violence is caused by politicians who want to win election at all cost". 


\section{Gubernatorial Elections in Ekiti State}

In every democratic system of governance, election is the only legitimate determinant entrance to political office or leadership and it is an important element for facilitating good governance practices and consolidation of democracy. Elections provide avenue for the electorates to express their will and sovereignty and give legitimacy to their political leaders. Elections have become the most acceptable method by which citizens of an ever increasing number of political systems choose their leaders (Tanimu 2008). The appeal of elections lies principally in the opportunity that it provides for entire electorates to participate in choosing those that should govern them in a simple and peaceful exercise (Momoh, 2005).

Ekiti state since its creation in 1996 has witnessed five (5) gubernatorial elections. As the state grows in ages, political violence during gubernatorial elections is growing at an alarming rate. This trend should be a source of worry to all well-meaning indigenes of Ekiti State who want peace and progress for the state. The preelection violence witnessed during the just concluded gubernatorial election in the state (where the governor of the state was assaulted by the security agents) clearly shows that all hands must be on deck to end this ugly trend in the state. The first gubernatorial election was in 1999 and was won by Otunba Niyi Adebayo of the Alliance for Democracy (AD), the second gubernatorial election was conducted in the year 2003 and was won by $\mathrm{Mr}$ Ayodele Fayose of the People's Democratic Party (PDP) while the third gubernatorial election was held in 2007 and Chief Segun Oni also of the People's Democratic Party (PDP) extraction was declared the winner. However, this particular election was challenged at the election petition tribunal and was subsequently annulled by the Federal Court of Appeal sitting in Ilorin, Kwara state on the ground of widespread violence during the election and incoherent figures (results) as declared by the Independence National Electoral Commission (INEC). Therefore, the Appeal Court consequently declared the candidate of the opposition party, the erstwhile Action Congress of Nigeria (ACN), in the person of Dr Kayode Fayemi, who came second in the election, the authentic winner of the election in October,2010, thus ending the three and half years of Chief Segun Oni"s administration, who only has six months left. The fourth gubernatorial election was conducted in 2014 and Mr Ayodele Fayose also of the People's Democratic Party (PDP) was declared the winner making him the first Ekiti indigene to rule the state for a second term. The fifth gubernatorial election was conducted in 2018 and won by Dr Kayode Fayemi of the All Progressive Congress (APC) thus making him again to rule the state on second term and also making him to be the second indigene of the state to rule the state for second term.

Ekiti has been a very peaceful and loving people and this is largely due to its homogeneity in nature. But since the return of the present democracy, elections have been characterised by violence and anti-social activities. The state has now been notorious for violent electioneering. The 2007 gubernatorial election was marred by rigging, violence, killing, ballot boxes snatching, etc and made the opposition party that lost the election to challenge the outcome at the election petition tribunal and the Court Of Appeal sitting in in Ilorin ordered for rerun election in some affected electoral wards. The re-run election held in 2009 was also marred by rigging, violence (where aspirants for public office in Ekiti including the former world bank technocrat, Ayo Daramola, Tunde Omojola and Taye Fasuba, the then Chairman of Ado Ekiti Local Government were brutally murdered). The violence that took place during the rerun election was unprecedented that one Segun Ajayi lost his limb to the mayhem in Ado Ekiti. His decomposing limb was brought to the court by the erstwhile Action Congress of Nigeria $(\mathrm{ACN})$ as exhibit to prove that there was violence during the election. Likewise, one Kolawole who was a supporter of the Action Congress of Nigeria (ACN) in Ido Ekiti was shot at a close range by a mobile policeman who shattered his thigh bones and the thigh was consequently amputated at the Federal Medical Center, Ido Ekiti (now Federal Teaching Hospital). The decomposing thigh was also brought to both the election petition tribunal sitting in Ado Ekiti and court of appeal in Ilorin to prove the case of violence during the rerun election. In the like manner, the Independence National Electoral Commission (INEC) Local Government office which also served as the Local Government election results collation centre for Ido/Osi Local Government of the state was set ablaze with property worth millions of naira including election results were burnt. Due to these widespread of violence in the state during the rerun election and couple with the incoherent figures as declared by the Independent National Electoral Commission (INEC) and this made the opposition to challenge the results once again at the election petition tribunal and in 2010, the Court of Appeal sitting in Ilorin again annulled the election results and ordered that the candidate of the opposition, Dr Kayode Fayemi should be sworn in as the Governor.

However, in 1999, during the electioneering campaigns, there was violence involving Alliance for Democracy (AD) members. Some unknown hoodlums had unleashed mayhem on party members who were holding a ward meeting at the Matthew Area of Ado Ekiti on the fateful day. Also, an Alliance for Democracy (AD) woman leader died when she was bathed with acid. In 2003 election, violence believed to be caused by intraparty squabbles later festered and assumed full-scale crisis, though no life was lost. Between 2003 and 2007 elections, the state witnessed violence and many lives were lost, especially in 2005 and 2006. The killings were believed to be politically motivated. 


\section{Causes of Gubernatorial Election Violence in the State}

Corruption: Corruption especially on the part of both the political class and the Independence National Electoral Commission (INEC) is one of the factors responsible for electoral violence in the state. Corruption in the electioneering process is usually manifest in many ways, among which are;

(i)vote buying and voters inducement by the politicians

(ii)inducement of both the electoral umpire and the security agents by the politicians.

(iii)manipulation of figures by the electoral umpire

Nigeria, like most countries in the Sub-Sahara African region has been vigorously confronted with the malaise of corruption. Corruption is a cancer that has eaten deeply into the fabric of Nigeria polity, the global perception about graft in Nigeria is that it is generally acknowledged that corrupt practices are endemic and systematic in both private and public sectors in Nigeria (Philips \& Akpokighe, 2014).

Dike (2003) submitted that political corruption at the highest level of political authority in Nigeria. To him, corruption occurs when the politicians and other important state decision-makers, whose duties are to formulate and implement policies on behalf of the electorates, are themselves corrupt. Thus the spare of corruption in Nigeria has found expression not only in public officers and institutions but other critical social institutions namely: the family, schools, places of worship, electioneering activities, had had a fair share of corrupt practices bedevilling them.

The Corruption Perception Index (CPI) released annually by Transparency International has consistently listed Nigeria among the most corrupt nations in the world. The 1996 study of corruption by Transparency International and Goettingen University ranked Nigeria as the most corrupt nation among 54-nations listed in the study. The 1998 Transparency International Corruption Perception Index (CPI) ranked Nigeria as the fifth most corrupt nation out of 85 Countries listed in the rating. The 2001 Corruption Perception Index rated Nigeria second most corrupt nation among 91 Countries listed. The 2002 Corruption Perception Index (CPI) ranked Nigeria third most corrupt nation out of the 102 Countries listed. In 2003 Corruption Perception Index (CPI) also rated the Country as the second most corrupt nation out of 133 Countries listed. Although the trend improved a little from 2005 Corruption Perception Index ratings.

The Social Economic Rights and Accountability (SERAP) recently on its latest report titled "Combating and Corruption and Impurity in Nigeria: An Agenda for Institutional Reforms in Anti-Corruption Strategies" highlighted how corruption had bedevilled all facet in Nigerian society. The report showed the Nigerian Police as the most corrupt institution in the Nigeria. The report also indicated the Judiciary (the arm of the government that is expected to enforce law) and civil service as very corrupt.

The inability of Nigeria's past and present leadership to consolidate on the gains of democracy has been attributed to corruption. In general terms, corruption has eaten very deep and hence, found its way into the body polity of the Nigerian State, so much so that virtually all spheres of the nation's life stinks with the sources of corruption.

Preye and Wileyam (2011) argued that Nigerians no longer believe that honesty and integrity are not worthy principles since one can do very little or even do nothing at all to gain so much. The school of thought of Preye and Wileyam on the high degree of ineptitude and indolence in the attitude of Nigerians further confirm the fact that corruption is not a thing of the leadership alone; the followership is also guilty of this misdemeanour. Corruption whether political, economic, judicial, familial, institutional or bureaucratic could by and large impede the progress of any society where such attitudes are widely tolerated and accommodated in the scheme of things. The effects of corruption on the social fabric of society can be most damaging of all, it can undermine people's trust in the political system, in its institutions and its leadership, it can lead to frustration and general apathy among disillusioned public, resulting in a weak civil society (Transparency International, 2014).

Political corruption erodes and corrodes the meaning, mechanisms and the very essence of democracy. Political corruption breaks the link and people's power to influence collective decisions, contribute input into the system, affects voting patterns, generates general apathy for meaningful participation and basically overheats the policy due to public disaffection and disenchantment. In the midst of all these strand of corruption, it can be said that political corruption predominates.

The existence of political corruption in Nigeria is perceived as an aberration. This is because the actual practice of democratic principles rest squarely on the legal code of society. Thus, the existence of high incidence of political corruption tends to have more serious consequences on democracies more than any form of government. This is so because it poses dangerous omen to the principles of democracy. Nearly all the facets of the Nigerian society have been bedevilled with sharp practices and the politicians are not exempted. It is unfortunate that Nigerians did not know and/ or an idea of pay package of their elected officials' right from the least to the highest post. The politicians have been aiding and abetting corruption, the electioneering system has been commercialized and it is now cash and carry. Politicians do not believe much in campaign now, all they do is to look for avenue to induce voters with money to get votes.

Unemployment: Unemployment is another major factor contributing to electoral violence in the state. The issue 
of youth unemployment is a global social issue but has a higher rate in the developing world in particular. The problem of youth unemployment is very evident in Nigeria and Ekiti state is not an exception. The massive youth unemployment in any country is an indication of far more complex problems (Okafor, 2011). Our Universities and other tertiary institutions are producing thousands of graduates yearly without the equivalent means of giving them employment. This has consequently have a multiplier effects on the number of people roaming about the streets doing more or less nothing, the youth which ordinarily would have found gainful employment. The large number of youths who are unemployed is capable of undermining democratic process as they constitute a serious threat if engaged by the political class for clandestine activities (Adepegba, 2011, Ibrahim,2011,Lartey,2011, Olatunji \& Abioye, 2011). The political class has capitalised on the large number of unemployed youths in the country to employ them as political thugs before, during and after elections in the state. It is disheartening to know that the manner in which the political class are engaging the services of jobless youths as thugs for the purpose of intimidating the perceived opponent and their supporters during elections is growing in the state. The youths are often encouraged to unleash violence, cause electoral violence, break the law at will, in which virtually nothing can be done to stop them once they have made up their mind to unleash these havoc on their intended targets (Usman,2010).

High wages for Political Office Holders: Both high wages and power associated with the political office holders in Nigeria is one of the factors that had contributed to electoral violence in the state. A wage can be described as a monetary compensation paid by an employer to an employee in exchange for work done. The high wages for the political office holders in Nigeria makes electoral violence inevitable. For instance, the security vote of the governor is running to millions of naira every month. To make the matter worst, you cannot even query the governor of how the said security votes is being disbursed. The breakdown of the salaries and other emoluments of political office holders in Nigeria as released by Revenue Mobilization Allocation and Fiscal Commission (RMAFC) is as follows:

(a ) Basic salary

(b) Hardship allowance

(c) Constituency allowance

(d) Leave allowance

(e ) Accommodation/ Housing allowance

(f) Furniture allowance

(g) Duty Tour allowance

(h) Newspaper allowance

(i) Wardrobe allowance

(j) Recess allowance

(k) Utilities

(l) Domestic staff

(m) Entertainment

(n) Personal Assistant

(o) Vehicle Maintenance allowance

(p) Severance Gratuity

These various categories of allowances, apart from the fact that it is huge and bogus, the allowances are eating deep on the nation's economy, and this is while it has been said that Nigeria's political structure is highly capital intensive and very expensive to operate. The obnoxious welfare packages for political office holders have increased the level and the rate of political patronage in the country, and this has contributed to the volatility of the political space.

Inadequate Voters Education: Civic and voter education is a major component of the electoral process in Nigeria. Voter education is aimed at providing citizens of a democracy with the basic information about participating in elections. The law empowers the Independent National Electoral Commission (INEC) to conduct civic voter education in Nigeria.

A good and proper voter education is to include the following:

(i) How voter can verify registration at the polling centres

(ii) Persons who are qualified to vote

(iii) Where to vote

(iv) How to vote

(v) Voting procedure

(vi) Offences on election day

(vii)Conducts by political parties before, during and after elections.

When the above outlines are lacking, there is bound to be conflicts, either before, during or after elections. Lack of adequate and proper civic and voters education by major election stakeholders including the security agencies is affecting the conduct of peaceful, free and fair elections. 
Perceived lack of Independence by the Electoral Umpire (INEC): Perceived bias and unfair attitude by the nation's electoral body has been adjudged as another factor contributing to electoral violence in Nigeria. By the law that established the electoral body, INEC supposed to be independent to enable it conduct free, fair and transparent elections. But has INEC actually be independent to conduct elections?. However, the way INEC has carried out its duties has drawn criticism from all the political parties, including Human Right Watch. For instance, during the re-run gubernatorial election in Ekiti state in 2009, the state INEC Commissioner said she was being pressurised to announce a fake result and this was against her conscience, though she never mentioned which of the political parties or personalities pressurising her to announce fake results for the election. INEC has been accused on several occasions of working for some selected politicians and/or political parties to influence the outcome of elections, though the allegation may not be substantiated in most cases. In the recently concluded gubernatorial in Osun state, INEC was accused of working with the ruling party, the All Progressive Party, APC to influence the results of the election in favour of the ruling party

\section{Remedies to Gubernatorial Election Violence in the State}

Judiciary Reforms: Judiciary constitutes a vital position in any democracy. Judiciary is therefore expected to ensure that the legislative and the executive arms of government keep faith with the cardinal goals of democracy, good governance and above all observance of rule of law, fundamental doctrine of separation of power, independence of judiciary, and check and balances (Abdul-Qadir 2012, Abdulqadir, 2012, Shehu, 2012, ImmamTamim, 2012, Abdulraheem, 2012). The judiciary is expected to be above board and be free of corrupt practises but when the judiciary is involved in corrupt practises, it would not be fear to political class, hence violence is inevitable. If the judiciary considered to be the beacon of a democratic process and a good governance is tainted in corruption, the developmental objectives of the country will remain a mirage (Obutte, 2016). The judiciary should demonstrate absolute and total independence from both the legislative and the executive arms to enjoy the total confidence of the citizens. Courts should restrain itself from granting frivolous and flimsy exparte orders to the political class. Cases involving electoral petitions should be treated with dispatch to avoid unnecessary pressure on the Court.

Election Violence Commission: The Federal Government should establish The Electoral Violence Commission. This Commission would be saddled with the responsibility of investigating and trying anyone found to have involved in any form of violence before, during and after elections. Terms of Reference and the responsibilities of the Commission should be well defined to avoid clashes with the Police and the Court. Membership of the Commission should comprise of people who are not politicians and of good character. Retired judicial officers should also be part of the Commission.

Reduction in the Wages of Political Office Holders: Let the political office holders be placed on a national minimum wage like the civil servants in the country. This will reduce do or die attitudes of the politicians. It has been said severally that political class in Nigeria is the highest paid in the world, reducing the wages of the politicians will make the political posts less attractive, and anyone with genuine interest will always contest for elective positions.

Total Independence of Electoral Umpire (INEC) : INEC has the name implies is supposed to serve as an independent and effective Electoral Management Board for the country. INEC is supposed to be committed to the conduct of free, fair, credible and transparent elections in the Ekiti state in particular and Nigeria in general for sustainable democracy in the state and in the country. INEC should embrace electronic voting so that election results can be released as fast as possible to reduce post-election tensions. Also, electronic voting will reduce incidences of electoral malpractices like ballot stuffing, results sheets mutilation, manipulations, over-voting, etc. Internet voting system have gained popularity and have been used for government elections and referendums in the United Kingdom, Estonia and Switzerland as well as municipal elections in Canada and primary elections in the United States and France (McGaley \& Gibson, 2003). Some of the benefits of electronic voting are:

(i) It eliminates human errors

(ii) Easy voters identification

(iii) Satisfaction of voters desire

(iv) Easy sorting and counting of the results with bias

(v) It guarantees openness and this will bring confidence among the aspirants and the voters

\section{REFERENCES}

Abdul-Qadir Zubair, Abdulqadir I.A, Yusuf I.A, Shehu A.T, Immam-Tamim \& Abdulraheem T.A (2012)

"Judicial Reform in a Democratised Nigeria". Conference Paper presents at National Association of Law

Teachers held on July, 2012.

Adepegba A (2011) "Police Arrest 51 Over Post Election Violence”. The Punch, Saturday.

Adesina Adetola (2008) "Ekiti Kete: The Value and the Vision".

Alausa D.W \& Akingbade L.O (2017) "Electronic Voting: Challenges and Prospects in Nigeria’s Democracy”. 
The International Journal of Engineering and Science. Vol.6 pp67-76.

Ayodele Afolabi (2018) “Ekiti 2018: Residents, Voters Express Concern Over Electoral Violence”. Saturday Punch

Bello. I (2017) "Poverty and Violence in Nigeria- Implication on Democracy". Journal of Poverty, Investment and Development. Vol.33.

Dike A.T (2003) "The Sociology of Politics". International Journal on Political and Social Science.

Ibrahim. I (2011) “Nigeria, A Divided Country”. Newswatch, 53(18), 19-22.

Jide Ojo (2018) "Electoral Violence, Vote Buying and Nigeria's Future Elections”. The Punch Newspaper.

Lartey. O (2011) "Four Burnt Alive, 45 Prison Inmates Released in Kaduna". The Punch Newspaper, $30^{\text {th }}$ April,2011.

McGaley M \& Gibson J.P (2003) “Electronic Voting: A Safety Critical System”. National University of Ireland, Maynooth Oostveen.

Momoh A (2005) "Democracy or Good Governance Making Sense of Disempowerment in Nigeria". The Guardian Newspaper.

Obutte P.C (2016) "Corruption, Administration of Justice and the Judiciary in Nigeria". Available at https://ssrn.com/abstract.

Okafor E.E (2011) "Youth Unemployment and Implication for Stability of Democracy in Nigeria". Journal of Sustainable Development in Africa. Vol.13 No.1

Okeke R.C \& Idike A.N (2017) "The Judiciary and Democracy Consolidation in Nigeria Under Buhari Administration". Specialty Journal of Politics and Law. Vol.2 pp24-32

Olatunji.S \& Abioye. O (2011) "Lecturers, Students, and Others Killed in Kaduna”. The Punch 20 $0^{\text {th }}$ April, 2011.

Philips. O.O and Akpokighe O.R "Corruption in Nigeria: The Possible Way Out". Global Journal of Human Social Science. Vol.14.

Preye A.P \& Wileyam S.H (2011) “Corruption in Politics”. A Socio-Political Journal of Nigeria Studies.

Report of Transparency International, 2014.

SERAP's Report and the Anti-Corruption Crusade

Tanimu A.K (2008) "Violence and the Electoral Process in Nigeria: A Case Study of the 2007 Gubernatorial Election in Plateau State".

Usman. A (2010) "The Curse of Democracy in Northern Nigeria". The Guardian Newspaper, 6" June,2010. 